\title{
Can RDW be Added to Intensive Care Disease Severity Scoring Systems?
}

\author{
Ayse Sahin Tutak*, Huseyin Avni Findikli \\ Department of Internal Medicine, Adiyaman University of Medical Faculty, Adiyaman, Turkey
}

*Corresponding Author: Ayse Sahin Tutak, Department of Internal Medicine, Adiyaman University of Medical Faculty, Adiyaman, Turkey, Tel: +904162161015; Fax: +904162161015; E-mail: aysesahintutak@hotmail.com

Received: 24 October 2018; Accepted: 09 November 2018; Published: 12 November 2018

\begin{abstract}
Intensive care services are high-cost services. The functioning, efficiency, and cost-effectiveness assessments of the intensive care units (ICU) should be performed according to the severity of the disease of the treated patients. For this purpose, various disease severity scores have been developed to be used in ICU. Of these severity scores, APACHE II is mostly used. The mortality prediction rates of APACHE II are high, but not $100 \%$. Various severity scores have been developed over time, but none of them has been completely accurate in predicting mortality. Today, there are numerous studies related to the mortality by Red Cell Distribution Width (RDW). In the studies conducted on a relationship between RDW and mortality in ICU patients with different diagnosis, its relationship with mortality is clear. In this study, we have examined the publications in which laboratory parameters of APACHE II have been extensively reviewed in the literature and compared with mortality one by one and the publications in which RDW has predicted mortality. We believe that the addition of RDW as a laboratory parameter to APACHE II will have high contributions in predicting mortality.
\end{abstract}

Keywords: Intensive Care; APACHE II; RDW (Red blood cell distribution width); Mortality

\section{Historical Development of ICU}

Historically, the term "intensive care" was first introduced in 1863 when Florence Nightingale defined the units where the patients who recovered from the acute phase after surgery and stayed until their vital functions were stabilized in his notes and in the 1920s, post-operative "recovery room" was defined in Johns Hopkins Hospital; in 1930, a well organized postoperative intensive care unit was established in Germany; in the 1940s, highly specialized post-operative "recovery rooms" were introduced in Mayo Clinic in the United States [1] and today's foundations of the ICU have begun to be laid.

Archives of Clinical and Biomedical Research- http://archclinbiomedres.com/ - Vol. 2 No. 6 - Dec 2018. [ISSN 2572-5017] 


\section{ICU Disease Severity Scores}

Intensive care scoring systems are commonly used to predict the recovery from the disease, to determine the severity of the disease and the degree of organ dysfunction, to evaluate the treatments administered, to standardize the patients to participate in clinical trials, and to compare ICU performance [2]. The factors determining mortality in intensive care patients are the physiological reserve of the patient, the type of disease, the severity and the response to treatment. In addition, chronological age and chronic diseases can cause deterioration in functions of organ systems and affect the patient's physiological reserve. The severity of the disease can also be evaluated anatomically or via the functions [3]. During the admission to intensive care, the diagnosis of many patients could not be determined. Therefore, scoring systems based on physiology are used because it is not possible to apply diagnostic scoring systems. The one defining the severity of disease by using changes in physiological measurements is Acute Physiology and Chronic Health Evaluation = APACHE. APACHE I, one of the prognostic scoring systems, was developed in 1981 [4]; and APACHE II [5] was published and started to be used in 1985, APACHE III [6] in 1991, APACHE IV [7] in 2006. APACHE III is an extremely powerful scoring system, which is a detailed and simplified form of APACHE II, with the extension of the section of disease diagnosis, the addition of an area where the patient was admitted to intensive care, the human immunodeficiency virus and hematological malignancies to the evaluation. However, the evaluation did not find a common use area because it required the purchase of a computer-based software [6-10]. In APACHE IV, the diagnosis of admission to intensive care, duration of stay in the hospital before intensive care, mechanical ventilation and thrombolytic therapy have been added, but this has not been commonly used $[7,8,10]$. Because of these reasons in our country, APACHE II is commonly used in ICUs.

\section{APACHE II and Mortality Prediction}

APACHE II, which is one of the most used scores in ICUs, is known to show a good correlation with mortality. In APACHE II, body temperature, mean arterial pressure, heart rate, respiratory rate, oxygenation, arterial $\mathrm{PH}$, venous $\mathrm{HCO}_{3}$, sodium, potassium, serum creatine, hematocrit, leukocyte and GCS (Glasgow Coma Score: GCS) are included [5].

The range of scores available for APACHE II is between 0 and $71[5,11]$. In the study of Knaus and his colleagues in 5815 intensive care patients, it was determined that the mortality was 40-75\%, while APACHE II score was 20-35 for all nonoperative patients [5].

\section{RDW and the cases in which it has increased}

RDW is a measure of the volume variability of erythrocytes (anisocytosis) and is identified on a routine complete blood count. RDW is calculated with the formula of multiplying the standard deviation of the erythrocyte volume with the average rate of erythrocyte volume by 100 . It is included in the laboratory results as a standard statistical value. The normal range of RDW is between $11 \%$ and $14.5 \%$. The increase in RDW shows a large variety in erythrocyte volumes [12]. RDW increases in iron deficiency, vitamin B12 deficiency, folate deficiency and hemolysis, blood transfusion [13]. Increases in RDW have been found to be associated with increased inflammatory markers $[14,15]$. The effect of inflammation on erythropoiesis and circulating erythrocyte half-life causes anisocytosis and may lead to an increase in RDW values [16]. 


\section{Effects on RDW and Mortality}

It has been reported that a high RDW level has an important role for short- and long-term prognosis [17]. Although the underlying mechanism has not been fully understood, it has been shown that there is an independent relationship between increased RDW levels and all causes of mortality in critical patients [18]. Most importantly, it is suggested that the RDW value is an independent and strong indicator for the risk of death in the general population [17].

In a study based on the criteria of mortality, 15852 patients were examined retrospectively between 1988-1994. In a 8.7year average follow-up, 2.629 deaths were detected among 15,852 participants. In this study, mortality rates increased with increasing RDW value and the highest RDW value was found to be associated with a 5-fold increased risk of death when compared to those of the lowest [19]. In another study were conducted on 8175 patients aged 45 and over. For every $1 \%$ increase in retrospective RDW, it was concluded that the risk of all-cause mortality increased by $22 \%$ [20]. In a systemic meta-analysis published in 2017 where a total of 117047 CRF patients were examined, it was reported that the risk of allcause mortality increased by $36 \%$ in hemodialysis patients for every $1 \%$ increase in RDW and to have concluded that high RDW levels probably increased the risk of all-cause mortality in CRF patients as a result of this study [21]. In the metaanalysis where a total of 12 studies involving 2721 patients were examined, it was concluded that higher RDW levels were associated with increased risk of atrial fibrillation in different populations [22]. In another study, it was also determined that RDW had a prediction, close to APACHE II in predicting intensive care mortality and emphasized that RDW should be considered to be added to the disease severity scores [23].

\section{Conclusion}

The mortality prediction rates of APACHE II in disease severity scoring are high but not $100 \%$. In clinical use, the mortality prediction rates of APACHE II, which we use frequently in ICU, have been observed to be low at some points and then APACHE III and APACHE IV have been developed. However, these scoring systems could not be used as effectively as APACHE II due to the need for computer-based software (APACHE III) and the presence of mechanical vents, thrombolytic treatment and ICU admission diagnoses (APACHE IV).

In this study, we see that scientists are still in search for the prediction of mortality near $100 \%$ in such commonly used scoring systems and various different parameters have been added in these researches over the years. Besides in this study, we have also reviewed the mortality prediction rates of RDW in general and disease populations. As seen in these studies, we believe that RDW has an effective prediction mortality as well as predicts the mortality of the laboratory parameters that constitute APACHE II and therefore RDW should be considered to be added to the disease severity scores.

\section{References}

1. Varon J, Acosta P. Approach to the intensive care unit (ICU). In: Handbook of critical care and intensive care medicine. 2nd ed. Springer 2010: 1-10.

2. Bouch DC, Thompson JP. Severity scoring systems in the critical ill. Continuing Education in Anesthesia and Critical Care 8 (2008): 181-185. 
3. Ball JAS, Redman JW, Grounds RM. Severity of illness scoring systems. In: Vincent JL (ed). 2002 Yearbook of Intensive Care and Emergency Medicine. Berlin. Springer 2002: 911-933.

4. Knaus WA, Zimmerman JE, Wagner DP, Draper EA, Lawrence DE. APACHE- Acute physiology and chronic health evaluation: a physiologically based classification system. Crit Care Med 9 (1981): 591-597.

5. Knaus WA, Draper EA, Wagner DP, Wagner DP. APACHE II: A severity of disease classification system. Crit Care Med 13 (1985): 818-829.

6. Knaus WA, Wagner DP, Draper EA, Zimmerman JE, Bergner M et al. The APACHE III prognostic system risk prediction of hospital mortality for critical III hospitalized adults. Chest 100 (1991): 1619-1636.

7. Zimmerman JE, Kramer AA, Mcnair DS, Malila FM. Acute physiology and chronic health evaluation (APACHE) IV: hospital mortality assessment for today’s critically ill patients. Crit Care Med 34 (2006): 1297-1310.

8. Keegan MT, Gajic O, Afessa B. Severity of illness scoring systems in the intensive care unit. Crit Care Med 39 (201): 163-169.

9. Karabıyık L. Yoğun bakımda skorlama sistemleri. Yoğun Bakım Dergisi 9 (2010): 129-143.

10. Kılıç YA. Yoğun bakım skorlama sistemleri: Neden, nasıl, biz nerdeyiz? Yoğun Bakım Dergisi 2 (2002): $26-31$.

11. Knaus WA, Draper EA, Wagner DP, et al. An evaluation of outcome from intensive care in major medical centers. Ann Intern Med 104 (1986): 410-418.

12. A-Marsh WL, Bishop JW, Darey TP. Evaluation of red cell volume distribution width (RDW). Haematol Pathol 1 (1987): 117-123.

13. Duffy TP. Approach to the patient with anemia. In: Duffy TP, Kelly WN, Dupont HL, Glick JH, Harris ED, Hathaway DR et al, editors. Kelly’s Textbook of Internal Medicine. Philadelphia: Lippincott Williams \& Wilkins, 1997: 1295-1299.

14. Lippi G, Targher G, Montagnana M, Salvagno GL, Zoppini G, Guidi GC. Relation between red blood cell distribution width and inflammatory biomarkers in a large cohort of unselected outpatients. Arch Pathol Lab Med 133 (2009): 628-632.

15. Perlstein TS, Weuve J, Pfeffer MA, Beckman JA. Red blood cell distribution width and mortality risk in a community-based prospective cohort. Arch Intern Med 169 (2009): 588-594.

16. Weiss G, Goodnough LT. Anemia of chronic disease. N Engl J Med 352 (2005): 1011-1023.

17. Salvagno GL, Sanchis-Gomar F, Picanza A, et al. Red blood cell distribution width: A simple parameter with multiple clinical applications. Crit Rev Clin Lab Sci 52 (2015): 86-105.

18. Kim CH, Park JT, Kim EJ, et al. An increase in red blood cell distribution width from baseline predicts mortality in patients with severe sepsis or septic shock. Crit Care 17 (2013): R282.

19. Perlstein TS, Weuve J, Pfeffer MA, Beckman JA. Red blood cell distribution width and mortality risk in a community-based prospective cohort. Arch InternMed 169 (2009): 588-594.

20. Patel KV, Ferrucci L, Ershler WB, Longo DL, Guralnik JM. Red blood celldistribution width and the risk of death in middle-aged and older adults. Arch Intern Med 169 (2009): 515-523.

21. Zhang T, Li J, Lin Y, Yang H, Cao S. Association Between Red Blood Cell Distribution Width and All-cause Mortality in Chronic Kidney Disease Patients: A Systematic Review and Meta-analysis. Arch Med Res 48 (2017): $378-385$. 
22. Shao Q, Korantzopoulos P, Letsas KP, Tse G, Hong J, Li G, Liu T. Red blood cell distribution width as a predictor of atrial fibrillation. J Clin Lab Anal 2018.

23. HA Findıklı,A Sahin Tutak, A Gürbüzcan. The Prognostic Potential of Red Blood Cell Distribution Width Values In Intensive Care Unit Patients. Int J Recent Sci Res 9 (2018): 27891-27895.

Citation: Ayse Sahin Tutak, Huseyin Avni Findikli. Can RDW be Added to Intensive Care Disease Severity Scoring Systems?. Archives of Clinical and Biomedical Research 2 (2018): 183-187.

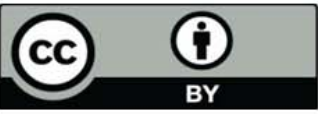

This article is an open access article distributed under the terms and conditions of the Creative Commons Attribution (CC-BY) license 4.0 